Tadeusz Wojewódzki

Wydział Europeistyki, Politologii i Dziennikarstwa

Ateneum - Szkoła Wyższa w Gdańsku

e-mail:wojewodzki@wojewodzki.pl

\title{
Standaryzacja zapisu treści jako warunek efektywnej praktyki infobrokerskiej
}

DOI: $10.12775 /$ TSB. 2014.008

STRESZCZEnIE: Edukacja infobrokerska - zarówno w postaci studiów podyplomowych, jak i wyprofilowanych specjalności studiów humanistycznych - systematycznie poszerza krąg absolwentów studiów wyższych, zorientowanych w problematyce komunikacji wiedzy na tyle, aby mogli oni samodzielnie kreować rozwój kultury infobrokerskiej w organizacji. Jest to obszar ważkich działań, warunkujących efektywność procesów decyzyjnych - a w konsekwencji możliwość odniesienia sukcesu i uzyskania przewagi nad konkurencją - nowoczesnymi metodami, właściwymi dla organizacji, które partycypują w procesach tworzenia wiedzy jako produktu finalnego.

Autoryzacja źródeł treści, standaryzacja ich form zapisu, racjonalizacja procesów kumulacji doświadczenia organizacji, dzielenia się wiedzą oraz optymalizacja transparentnych procesów decyzyjnych - to początek listy działań kreujących kulturę organizacji.

Praktyka infobrokerska prowadzi ostatecznie do powstania zapisu określonych treści. Zarówno ta w postaci klasycznej, ograniczającej się do usługi wyszukiwania określonych informacji, jak i w ujęciu infobrokerstwa systemowego - postrzegającego procesy komunikacji wiedzy w perspektywie problemowej relewancji wiedzy oraz uwarunkowań intelektualno-mentalnych organizacji. Efektywność praktyki infobrokerskiej odnoszona jest zazwyczaj do zawartości treści. Tymczasem standard zapisu treści - już na poziomie nazw plików - pozostaje w bezpośrednim związku z poziomem optymalizacji procesów komunikacji wiedzy. Analizując te standardy, poszukuje się optymalnej formy zapisu nazw 
plików jako najprostszego, a zarazem najbardziej masowego składnika procesów komunikacji wiedzy. We współczesnych organizacjach procesy te urosły do rangi krytycznego czynnika ich efektywności.

SŁOWA KLUCzowE: infobrokerstwo systemowe; kwanty wiedzy; optymalizery; standaryzacja treści.

\section{Infobrokerstwo a infobrokerstwo systemowe}

W codziennej praktyce organizacji działania infobrokerskie utożsamiane bywają z rezultatami wyszukiwania potrzebnych treści. Jest to skojarzenie nie tylko trafne, ale zarazem bardzo korzystne dla absolwentów humanistyki, skoro ich umiejętności postrzegane są jako przydatne w praktyce każdej organizacji. Z tego choćby tylko powodu ma sens wyodrębnianie z szerszego obszaru, zaliczanego czy to do zarządzania wiedzą, czy zarządzania w ogóle - umiejętności, kultury i produktów infobrokerskich i badanie go jako względnie autonomicznej całości ${ }^{1}$. Przemawiają za tym nie tylko wspomniane względy natury praktycznej, ale także poznawczej.

Infobrokerstwo systemowe traktowane jest jako projekt wchodzący w skład Programu Humanistyki Zintegrowanej². Zapoczątkowała go poznańska szkoła metodologiczna, choć sama nazwa programu powstała

1 Por. G. Czapnik, Z. Gruszka, A. Walczak-Niewiadomska, Edukacja brokerów informacji na poziomie akademickim - zarys problematyki badań realizowanych $w$ Katedrze Bibliotekoznawstwa i Informacji Naukowej Uniwersytetu Łódzkiego, [w:] Biblioteka, książka, informacja i Internet 2010, pod red. Z. Osińskiego, Lublin 2010, s. 27-38.

2 Idee formułowane obecnie w projekcie infobrokerstwa systemowego deklarowane były wcześniej w formule regionalistyki (1973-1974), platformy, której dzisiejsza formuła najbliższa jest bodaj klastrom problemowym. Jej celem była interdyscyplinarna integracja badań naukowych nad regionem, zorientowana na racjonalizację procedur decyzyjnych dotyczących problemów społeczno-gospodarczych regionu. Obecnie założenia projektu regionalistyki skonkretyzowane zostały na poziomie organizacji i jej procesów decyzyjnych. Kwantowanie wiedzy jest propozycją problemowego porządkowania procesów komunikacyjnych. Propozycją, która ma wdrożenia częściowo tylko zindeksowane, ale przykładem jej zastosowań w edukacji może być sylabus przedmiotu technologia informatyczna Sebastiana Kotuły (http://syjon.umcs.lublin.pl/metacortex/ syllabus-subject-print/4141). Wdrożenia zamysłu kwantyfikowania wiedzy datuje się od 2002 r. Ośrodek Informatyki - Terenowy Bank Danych - Pomorski Urząd Wojewódzki w Gdańsku (OITBD PUW) rozpoczął wówczas prace nad systemem wsparcia działań administracyjnych kwantami wiedzy. Idea metodologii decyzyjności ukierunkowanej 
nieco później. Niemniej łącznikiem refleksyjności nad celowymi działaniami jednostek i zespołów była i jest niezmienne perspektywa epistemologiczna, sformułowana przez Jerzego Kmitę oraz rozwinięta przez grono jego współpracowników3 . Przedmiotem zainteresowań tego nurtu dociekań jest obszar ponadindywidualnych przekonań akceptowanych czy też respektowanych przez jednostki - ich status, uwarunkowania i moc sprawcza. Infobrokerstwo systemowe - jako projekt o wyraźnie praktycznej orientacji metodologicznej ${ }^{4}$ - obejmuje zarówno diagnostykę

potrzebami administracji stanowiła punkt odniesienia dla prac prowadzonych w OITBD PUW. Kwanty wiedzy nazywano wówczas fiszkami. Jako element wsparcia decyzyjności funkcjonowały one od 2004 r. rutynowo wykorzystywane przez wojewodę. Ich obecność zauważona została przez środowisko informatyczne. Projekt rozwijany był następnie jako moduł decyzyjności w kilkunastu przedsięwzięciach finansowanych z funduszy unijnych. Produkty finalne tych projektów zawierają w sposób istotny procedury kwantyfikowania wiedzy. W 2009 r. firma CRM SA zainicjowała formułę komercyjną, gdzie kwantyfikowanie wiedzy stanowiło moduł rekomendowanych zmian - blokujących bariery mentalne, rozpoznane w części diagnostycznej - nazywanej Metodyką Syndromiczną (rozbieżności między przekonaniami deklarowanymi a respektowanymi, ujęte $\mathrm{w}$ syndromy barier mentalnych i paradygmaty myślenia). Por. T. Wojewódzki, Regionalistyka jako nauka praktyczna, „Studia Filozoficzne” 1974, nr 7, s. 153-162; A. Gontarz, Obywatel wszechwiedzacy. Fiszki w urzędzie, „Computerworld” 2005, nr 12, s. 28-31; Infobroker systemowy [online]. CRM S. A. Devoteam Consulting Company [dostęp 31 maja 2014]. Dostępny w World Wide Web: http://www.crm.com.pl/offer/27.

Por. Program Humanistyki Zintegrowanej realizowany w formule swego rodzaju projektów operacyjnych ma postaci tak metodologicznie różne, jak Infobrokerstwo Systemowe z jednej strony, a np. Gramatyka Kultury Europejskiej - z drugiej. Łączy je niewątpliwie perspektywa intelektualna skupiona na formule sposobu myślenia jako kategorii intelektualnej tworzącej osnowę zintegrowanej interpretacji humanistycznej. Terminu tego używa J. Kmita w: A. Radomski, Wywiad z prof. Jerzym Kmita, , Kultura i Historia” [online] 2002, nr 3 [dostęp 31 maja 2014]. Dostępny w World Wide Web: http://www.kulturaihistoria.umcs.lublin.pl/archives/108; zob. też: A. Pałubicka, Opozycja dwóch postaw wobec świata a koncepcja kultury Jerzego Kmity, „Filo-Sofija” 2011, nr 12, s. 145-158.

${ }^{3}$ Por. M. Bonecki, Jerzy Kmita - interpretacja humanistyczna i społeczno-regulacyjna koncepcja kultury, „Filozofia Publiczna i Edukacja Demokratyczna” 2012, nr 2, s. 178-198; J. Grad, Jerzy Kmita - uczony, nauczyciel akademicki, organizator życia naukowego, popularyzator nauki, „Filo-Sofija” 2011, nr 12, s. 19-68. M. Bonecki konstatuje: „[...] przedmiotem zainteresowań humanistyki zintegrowanej stają się systemy przekonań organizujące przestrzeń kooperacji, tj. zawierające praktyczne instrukcje dla działań oraz reguły ich kulturowej interpretacji". Cyt. za: M. Bonecki, Sensemaking - wiedza i kultura organizacji w świetle humanistyki zintegrowanej, „Filo-Sofija” 2013, nr 18, s. 53.

${ }^{4}$ Jarosław Boruszewski zwraca uwagę na specyficzne uwarunkowanie infobrokera systemowego we współczesnej organizacji: „Druga formuła to rozwijane w Polsce przez Tadeusza Wojewódzkiego infobrokerstwo systemowe. Infobroker systemowy jest 
organizacji, jak i rekomendację zmian. Przedmiotem zainteresowań infobrokerstwa systemowego są przekonania składające się na infrastrukturę intelektualno-mentalną organizacji ${ }^{5}$, a w szczególności procesy komunikacyjne, warunkujące jej efektywność. Przekonania - sposób myślenia rozpoznawany w postaci barier mentalnych, paradygmatów myślenia i piramid wartości - są swego rodzaju kamieniami milowymi, wytyczającymi ścieżki realizacyjne programu humanistyki realizowanego $\mathrm{w}$ projekcie Infobrokerstwa Systemowego.

Rozważania składające się na treść niniejszego szkicu koncentrują się wprawdzie na wybranym fragmencie procesów komunikacyjnych, ale reprezentatywne są dla jednego z najnowszych projektów realizowanych w ramach Programu Humanistyki Zintegrowanej, jakim jest Infobrokerstwo Systemowe.

\section{Formula zapisu nazwy plików}

Stwierdzenie, że każda organizacja korzysta z zapisywanej przez siebie wiedzy, nie ma większej wartości heurystycznej. Ale pójście tylko o krok dalej i postawienie pytania - znamiennego dla infobrokerstwa systemowego - o to, jak ową wiedzę zapisuje się i jak z tych zapisów korzysta, szczególnie w sytuacjach problemowych, ukierunkowuje pytającego na obszary refleksyjności ważkiej intelektualnie i zarazem istotnej praktycznie. Jest to obszar zależności między komunikacją wiedzy a efektywnością organizacji.

interdyscyplinarnym specjalistą zajmującym się procesami informacyjnymi. Funkcjonuje jako pracownik konkretnej organizacji i współpracuje w ramach systemu, respektując ustalone formy zapisu treści, i udostępnia wyniki swojej pracy uczestnikom systemu na określonych zasadach. Będąc pracownikiem konkretnej organizacji, infobroker systemowy ma dostęp do informacji, których nie można powierzyć niezależnemu infobrokerowi z zewnątrz”. Por. J. Boruszewski, Jakość i wiarygodność informacji w infobrokerstwie, „Lingua ac Communitas" 2012, vol. 22, s. 241-250; T. Wojewódzki, Infobrokerstwo - jako nowa płaszczyzna wsparcia administracji publicznej, [w:] Społeczeństwo informacyjne 2005, pod red. G. Bliźniuka, J. S. Nowaka, Katowice 2005, s. 168.

${ }_{5}$ Por. T. Wojewódzki, Zarządzanie projektami [online]. Nf.pl [dostęp 31 maja 2014]. Dostępny w World Wide Web: http://manager.nf.pl/metodyka-zarzadzania-projektami „13160,11. 
Z normatywnej części rozważań, a więc obszaru rekomendowanych zmian wykluczyć trzeba nazwy dokumentów ${ }^{6}$, gdyż te funkcjonują we własnym obiegu, respektującym regulacje finansowe, prawne itd. Sposób ich zapisywania może być regulowany innymi preferencjami i zasadami nadrzędnymi wobec potrzeb komunikacyjnych. Natomiast w ujęciu problemowym (opisowym i eksplanacyjnym) interesujący wydaje się sposób zapisywania plików zawierających dane, informacje, wiedzę stanowiących przesłanki decyzji zarówno doraźnych, operacyjnych, jak i długoterminowych, strategicznych. Przykładem takich treści mogą być pliki dotyczące działań konkurencji, cenniki ich usług, opinie pracowników formułowane na forach publicznych itd. W obszarze zainteresowań pozostają zarówno wspomniane treści, jak i komentarze poczynione na ich marginesie. Gdzie takie komentarze są zapisywane? Jak do nich dotrzeć we właściwym czasie, kiedy mamy problem i poszukujemy wskazówek, podpowiedzi - słowem wszystkich treści pomocnych w jego rozwiązaniu?

Odpowiedzi dotyczących możliwych ścieżek realizacyjnych, pozwalających na efektywne wykorzystywanie wspomnianych treści, poszukuje się na ogół w informatyce. Specjaliści z tej dziedziny udzielają zazwyczaj aplikacyjnych podpowiedzi. Są to wskazania produktów mniej lub bardziej rozbudowanych - wymagających jednak zawsze pomyślnego wdrożenia ${ }^{7}$. Tymczasem w prowadzonych tu dywagacjach chodzi o rozwiązanie nie tyle informatyczne, co informacyjne, oparte na zastanym w danej organizacji środowisku informatycznym i możliwych do wprowadzenia małymi krokami, bez uruchamiania całej machiny wdrożeniowej. Zasadniczy problem niniejszych rozważań można więc sformułować następująco: Jak wykorzystać nazwę pliku, aby zawarta

${ }^{6}$ Jest to ograniczenie nałożone jedynie na zakres tematyczny: format zapisu plików. Dokumenty uczestniczą natomiast we wszystkich procesach komunikacyjnych w zakresie wyznaczonym funkcją ich problemowej relewancji.

7 W korporacjach stosunkowo popularnym rozwiązaniem jest np. produkt firmy Microsoft - SharePoint. Problem w tym, że pliki i tak muszą mieć nazwy. Rozwiązania aplikacyjne niosą ze sobą ryzyko większej koncentracji na samym narzędziu i jego logice niż na problemie. Ponadto współpraca z kontrahentami może natrafiać na aplikacyjne ograniczenia, jeśli zaistnieje niezgodność środowisk informatycznych. Dlatego położenie akcentu na funkcjonalność rozwiązania, koncentracja na jego podstawowym module, jakim jest nazwa pliku, i potraktowanie jej jako najważniejszego nośnika procesu relewancji wiedzy ma, zdaniem autora, racjonalne przesłanki. 
w niej wartość komunikacyjna naprowadzała efektywnie na poszukiwane przez nas treści? Jak wykorzystać sam zapis pliku, aby stał się istotnym kreatorem jakości procesów komunikacji wiedzy? Jaki udział w tym procesie moga mieć infobrokerzy?

Formułowanie nazw plików jest rutynową, powszechną czynnością związaną z przetwarzaniem treści na wszystkich stanowiskach pracy. Tak więc podpowiedzi nadawania im określonych nazw, powiązane z korzyściami użytkowymi - są rozwiązaniem pozytywnie rokującym dla perspektywy ich bardziej masowych zastosowań.

Nazwa pliku jest formułą zapisu „meta”. W praktyce komunikacji tego poziomu zwykło się korzystać ze słów kluczy. Wybór rozwiązania sposobu zapisu nazw plików - opartego na słowach kluczach - jest istotnym ukierunkowaniem poszukiwanego przez nas rozwiązania optymalnej formuły zapisu, ale nie jest jeszcze rozwiązaniem samym w sobie. Rozstrzygnięcia wymaga wiele kwestii tak podstawowych, jak choćby zasada doboru słów kluczy, czyli tworzenia słowników, jakimi będziemy się posługiwali, konstruując nazwy plików. Jeśli jedynym czy najważniejszym kryterium byłaby adekwatność słów kluczy do cytowanych treści, mowa byłaby o poprawności filologicznej takiego rozwiązania.

Formułując kryteria wyboru słów kluczy stosowanych przy zapisie nazw plików, powinniśmy jednak dodatkowo uwzględniać praktyczne uwarunkowania procesów komunikacyjnych, cele, jakim one służą. Jeśli przyjmiemy, że celem opisywanych zabiegów jest wsparcie procesów decyzyjnych, a konkretnie - procesów rozwiązywania problemów to pojawi się inna, oprócz filologicznej, reguła: relewancji treści, czyli porządkowania jej ze względu na określony problem. Konkretnie - na jaki - określa strategia organizacji, a dokładniej wpisany w nią model organizacji ${ }^{8}$. Jeśli jest nim organizacja inteligentna ${ }^{9}$, to jej nadrzędnym celem jest rozwiązywanie problemów oraz wdrażanie dobrych praktyk do standardów rutynowego działania. Problem - jego identyfikacja

${ }^{8}$ Realnie funkcjonujące modele plasują się między wartościami tak skrajnymi, jak „wyścig szczurów” z jednej, a organizacja inteligentna z drugiej strony.

${ }_{9}$ Definicję organizacji inteligentnej autor dookreśla, nawiązując do przemyśleń W. Marciszewskiego w pracy Szkice do współczesnej metodologii nauk społecznych [online]. Warszawa: Fundacja na rzecz Informatyki, Logiki i Matematyki, 2002 [dostęp 31 maja 2014]. Dostępny w World Wide Web: http://www.calculemus.org/SzkiceMet/ index.html. 
i rozwiązanie - jest tutaj regulatorem zasobów słów kluczy (słownika) (rys. 1) oraz operacji na nich (ich selekcji i hierarchizacji). Tak więc proces formułowania zapisu plików wkomponowany jest w szerszy kontekst rozwiązań komunikacyjnych obszaru wiedzy.

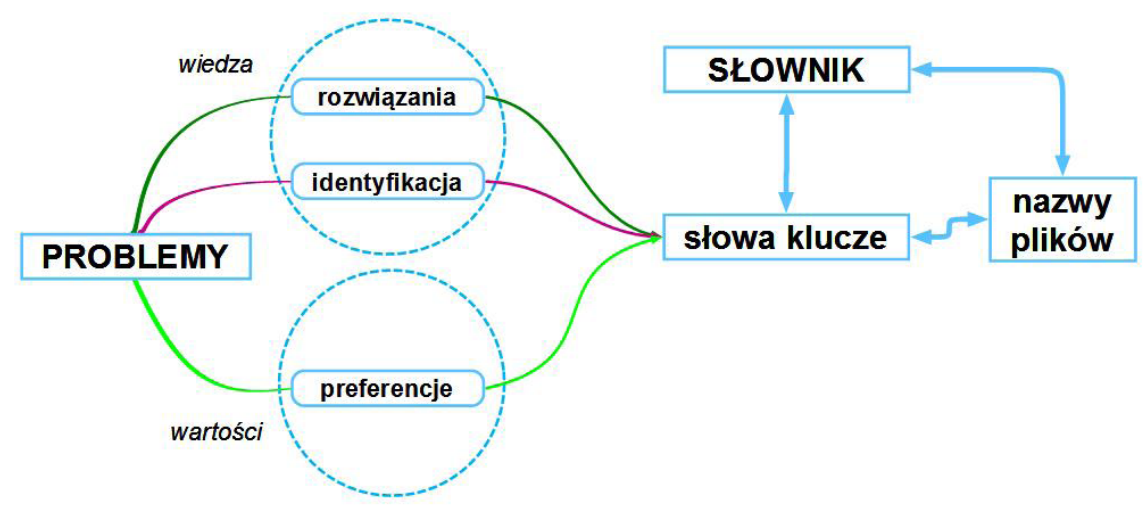

Rysunek 1. Słownik słów kluczy w procesach komunikacji wiedzy Źródło: opracowanie własne.

Strumienie wiedzy pojawiające się w organizacji mają charakter nie tylko przedmiotowy, dotyczący stanów rzeczy wyznaczonych problemami, ale także kategoryzujący te problemy. Technikami wspierającymi te procesy są mapy myśli. Skategoryzowany problem - przedstawiony w postaci mapy myśli - pełni jednocześnie funkcję porządkującą obszary słów kluczy, a tym samym stanowi istotne wsparcie procesu standaryzacji nazw plików.

Warto zwrócić przy okazji uwagę na wieloaspektowość identyfikacji problemu oraz skalę zagrożeń ścieżki poprawności analizy problemowej (rys. 2). Nie jest to zapewne pełny obraz uwarunkowań, ale jego interdyscyplinarność dobrze ilustruje skalę złożoności procesu tego rodzaju analiz oraz zakres kompetencji pracowniczych zespołów zaangażowanych w identyfikację problemu. Znaczna ich część pokrywa się z kompetencjami infobrokerskimi, w tym infobrokera systemowego ${ }^{10}$. Tak

${ }^{10}$ Różnice między kompetencjami infobrokera oraz infobrokera systemowego sformułowane zostały w 2008 r. Por. T. Wojewódzki, Infobroker a infobroker systemowy 
więc zauważalna jest konieczność obecności w zespołach analitycznych humanistów ukierunkowanych komunikacyjnie. Owo ukierunkowanie obejmuje zarówno klasyczne umiejętności infobrokerskie (wyszukanie informacji, wiedzy), jak i znaczne obszary infobrokerstwa systemowego (problemowe ukierunkowanie procesów komunikacyjnych podporządkowane formule relewancji) oraz elementy metodyk zarządzania projektami (wiedza metodyczna ${ }^{11}$ ).

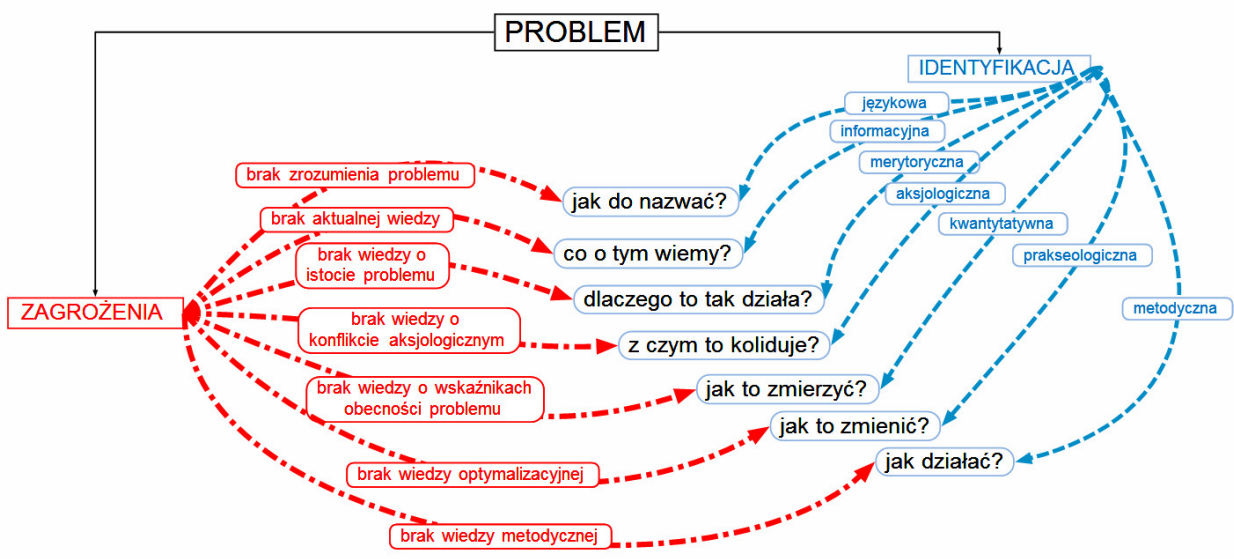

Rysunek 2. Zagrożenia procesu identyfikacji problemu Źródło: opracowanie własne.

Powracając do głównego wątku przemyśleń, trzeba zaznaczyć, że logika prezentowanego tutaj stanu rzeczy jest następująca: czynnikiem efektywności organizacji są procesy komunikacyjne. Ich optymalizacja w organizacjach nastawionych na rozwiązywanie problemów - może się układać w procesie relewancji wiedzy. Fundamentem tego procesu jest słownik słów kluczy powstający w trakcie identyfikacji problemu (tworzenia drzewa problemu). Na tych samych słowach kluczach, tworzących

[online]. Infobrokerstwo.pl [dostęp 31 maja 2014]. Dostępny w World Wide Web http:// infobrokerstwo.pl/index.php?option=com_content\&task=view\&id=202\&Itemid=62.

11 Autor ma tutaj na uwadze przede wszystkim Zarządzanie Cyklem Projektu - metodykę stosowaną powszechnie w finansowaniu przedsięwzięć pochodzących z funduszy unijnych. Por. T. Wojewódzki, Rola PCM w kształtowaniu unijnej kultury organizacji, „Studia i Badania Naukowe. Europeistyka" 2011, nr 2, s. 125-139. 
drzewo problemu, a następnie drzewo wiedzy, opierają się nazwy plików. Tak utworzone pliki stanowią integralną część drzew wiedzy. Jeśli wyeksplikuje się - dodatkowo - drzewa celów i połączy ścieżkami realizacji obszary wiedzy z celami - powstanie produkt finalny w postaci drzew decyzyjności.

Mapę opisanego procesu przedstawić można skrótowo w postaci zaprezentowanej na rys. 3. Czynione tu rozważania dotyczą wprawdzie wszystkich elementów procesu, ale obecnie koncertują się na pewnym jego elemencie: zapisywaniu plików, które występują we wszystkich stadiach tworzenia wiedzy. Przede wszystkim stanowią składowe procesów identyfikacji problemu, która przebiegać może w płaszczyźnie uwarunkowań przyczynowo-skutkowych, funkcjonalnych i strukturalnych. Pliki wchodzą w skład drzewa problemu, budowanego, w swojej najgłębszej warstwie, w oparciu o kwanty wiedzy. Tutaj mamy do czynienia ze standaryzowaną formułą ich zapisu. Przekształcenie drzewa problemu w drzewo wiedzy jest konsekwencją identyfikacji stanu wiedzy określanego z perspektywy interesującego problemu. Wreszcie drzewa decyzyjności - przedstawiane w postaci map myśli - są produktem finalnym także zapisywanym w postaci pliku.

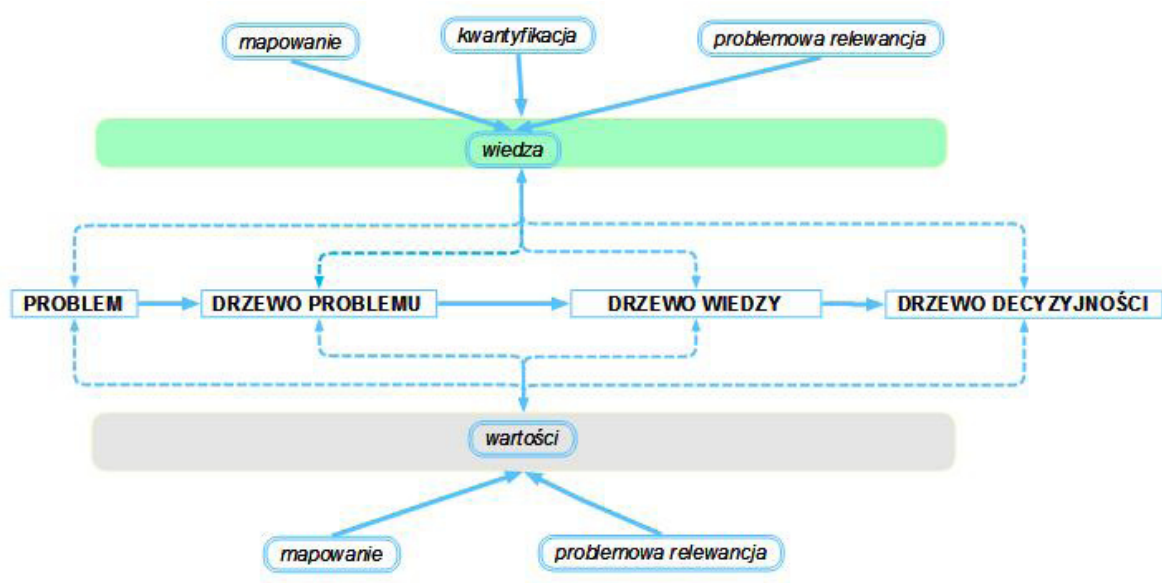

Rysunek 3. Produkty procesu komunikacji wiedzy Źródło: opracowanie własne. 
Waga problemu nazw plików zrelatywizowana jest do respektowanego modelu organizacji i wynikających z niego zasad działania. Przed omówieniem zasad, które znamionują przyjęty model organizacji, wytyczają zakres naszej refleksyjności i charakter przyjmowanych tutaj rozwiązań - konieczne jest dookreślenie cech wyróżniających refleksyjność nad organizacją, cech istotnych dla zrozumienia zasygnalizowanych preferencji.

\section{Humanistyka Zintegrowana jako program badawczy}

Waga problemu nazw plików pojawia się w określonym kontekście interpretacyjnym współczesnych organizacji, a szerzej - racjonalności ludzkich działań. W odniesieniu do organizacji rozumianych jako zespoły ludzkie nastawione na wspólną realizację celów: biznesowych, społecznych, administracyjnych - skupiamy się na warstwie, którą nazywamy infrastrukturq intelektualno-mentalnq. Racja stosowania takiej nazwy jest taka, że w powszechniejszym użyciu znajduje się pojęcie infrastruktury informatycznej, biurowej, logistycznej czy nawet infrastruktury społecznej ${ }^{12}$.

Infrastruktura intelektualno-mentalna to inaczej sposób myślenia ${ }^{13}$ organizacji. Zgadzamy się z Anną Pałubicką, że nie jest on dostępny bezpośrednio. Cechy znamienne dla sposobu myślenia organizacji określamy na podstawie analizy barier mentalnych, paradygmatów myślenia oraz piramid wartości. Ich identyfikacja ma po części charakter badań empirycznych, opartych na kwestionariuszach, wywiadach, analizach porównawczych dokumentów czy wreszcie rekonstrukcji logicznej - metod i technik łączących w praktyce badawczej metodologię ilościową - z jakościową. Istotna jest ponadto uwaga, że szczególną rolę w poznaniu specyfiki organizacji przypisujemy przekonaniom, które łączą określone cele (wartości) z wiedzą. Dla Programu Humanistyki Zintegrowanej istotne

12 E. Kozubek, P. Werner, Infrastruktura społeczna o znaczeniu międzynarodowym i krajowym - stan i prognoza. Pierwszy etap [online]. Warszawa: Ministerstwo Rozwoju Regionalnego, 2009, 35 s. [dostęp 31 maja 2014]. Dostępny w World Wide Web: http://www. mrr.gov.pl/rozwoj_regionalny/Polityka_przestrzenna/KPZK/Ekspertyzy/Documents/ Infrastruktura_spoleczna_o_znaczeniu_miedzynarodowym_i_kraj_etap129_05_09.pdf.

13 Terminologia wypracowana i stosowana w pracy: A. Pałubicka, Gramatyka kultury europejskiej, Bydgoszcz 2013. 
jest ponadto założenie o racjonalności, którego sens sprowadza się do konstatacji, że dysponując określoną wiedzą o sposobach realizacji wybranych celów, podmioty działające wybierają rozwiązania optymalne właśnie ze względu na zamierzone cele oraz wiedzę istotną dla ich realizacji ${ }^{14}$. W jeszcze ogólniejszej - epistemologicznej perspektywie - wybór prezentowanych tutaj rozwiązań oparty jest na złożeniach Humanistyki Zintegrowanej, odwołującej się do koncepcji wyjaśniania w nauce, autorstwa J. Kmity. Sedno tych przemyśleń dotyczy tzw. interpretacji humanistycznej jako znamiennego dla nauk humanistycznych sposobu wyjaśniania działań ludzkich, odwołującego się właśnie do przekonań pracujących podmiotów.

W badaniu infrastruktury intelektualno-mentalnej konkretnych organizacji porównujemy warstwę przekonań deklarowanych, zawartych $\mathrm{w}$ treściach programowych - np. takich jak strategia organizacji - $\mathrm{z}$ respektowanymi, identyfikując skale obecności syndromów barier mentalnych czy paradygmatów myślenia.

Postrzeganie efektywności działania danej organizacji, uwzględniające infrastrukturę intelektualno-mentalną, ukierunkowuje refleksyjność na stany rzeczy, które pomijane są w innych ujęciach. Uwaga powyższa istotna jest o tyle, że preferencyjne potraktowanie formuły zapisu treści jest konsekwencją m.in. rozpoznawania syndromu intelektualnej jednorazówki, stanowiącego element diagnostyki infobrokerstwa systemowego. Syndrom ów polega na tym, że w organizacji nie zapisuje się cząstkowych rezultatów pracy intelektualnej. Przykładowo: zadanie przygotowania raportu wymaga wsparcia szeregiem materiałów, które zabierają czas i energię organizacji. Wiele z nich było już wykonywanych wcześniej, ale nikt ich nie zapisuje lub robi to tak, że w praktyce nie istnieją one dla innych użytkowników. Zapisuje się ewentualnie tylko produkt finalny: sam raport. Obecność syndromu intelektualnej jednorazówki skutkuje pętlami zadaniowymi - wykonywaniem tych samych czynności po wielokroć. Zmniejsza to efektywności organizacji, a tym samym jej konkurencyjność.

14 Więcej na temat założenia o racjonalności: J. Kmita, Interpretacja humanistyczna i społeczno-regulacyjna koncepcja kultury, „,Filozofia Publiczna i Edukacja Demokratyczna” 2012, nr 2, s. 178-198. 


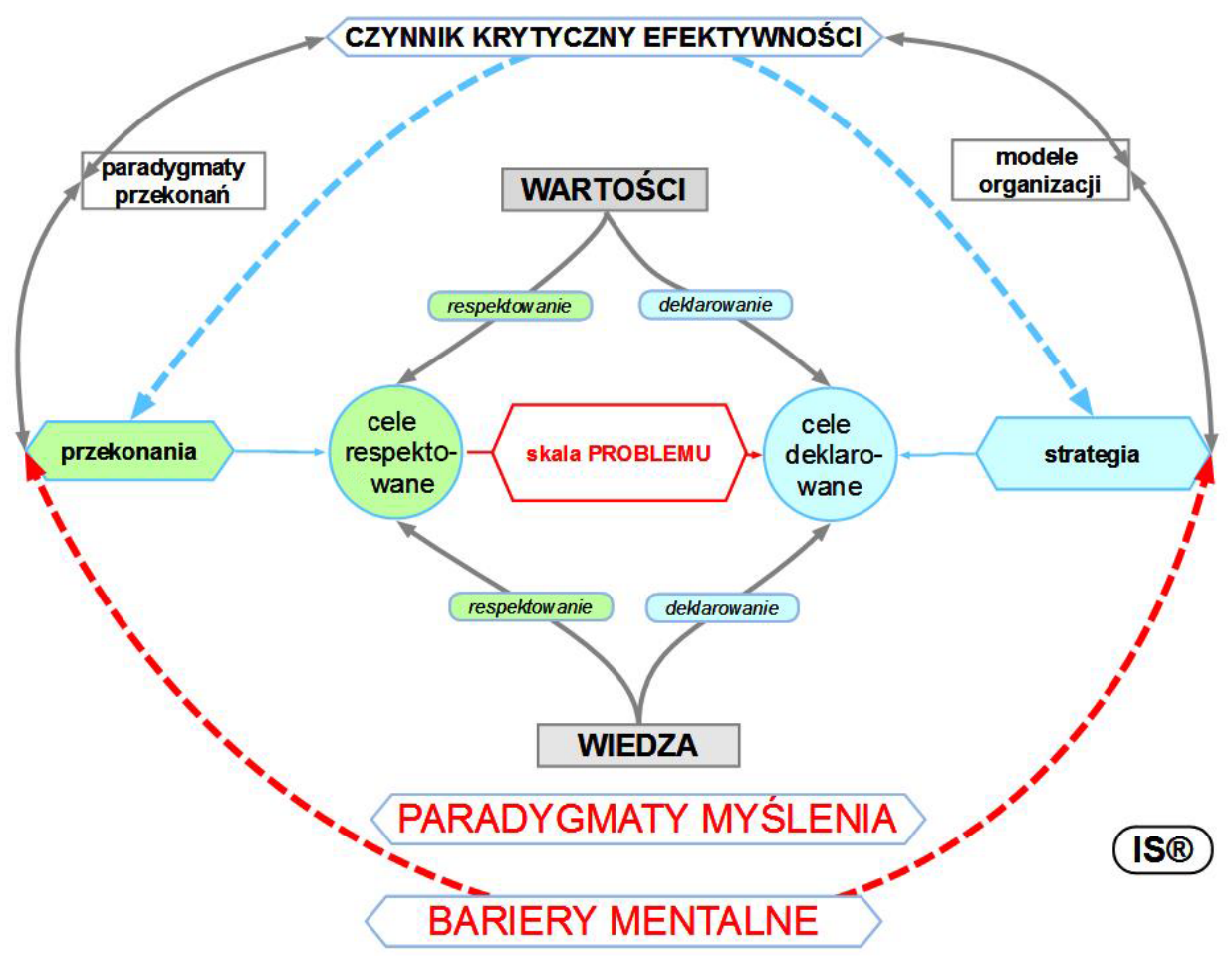

Rysunek 4. Czynniki krytyczne efektywności organizacji

Źródło: opracowanie własne.

Taki stan rzeczy widoczny jest wtedy, kiedy rozpoznaje się wspomniany syndrom. W konsekwencji dostrzega się konieczność zapisywania treści, które wcześniej nie były utrwalane. Dostrzega się potrzebę zapisywania plików w formule wpierającej istotnie procesy komunikacyjne, a szczególnie wiedzotwórcze. Tym samym formuła zapisu plików staje się problemem istotnym dla efektywności procesów komunikacyjnych.

Propozycje rozwiązania problemów zależą ponadto od innych uwarunkowań, m.in. od tzw. pryncypiów, czyli najbardziej ogólnych zasad respektowanych zarówno w praktyce badawczej, jak i zarządczej, a w omawianym przypadku - w praktyce infobrokerskiej. 


\section{Pryncypia infobrokerstwa systemowego}

Autor niniejszego tekstu nie będzie omawiał w tym miejscu wszystkich pryncypiów, ale dwa z nich mają szczególne znaczenie dla infobrokerstwa systemowego. Są to: Brzytwa Ockhama ${ }^{15}$ i Jajko Kolumba ${ }^{16}$.

Brzytwa Ockhama jest zasadą streszczającą się w dyrektywie niemnożenia bytów ponad niezbędną konieczność. Odnosząc ją do naszych analiz, można stwierdzić, że jej respektowanie wyraża się w poszukiwaniu jednej formuły porządkującej procesy komunikacji wiedzy. W infobrokerstwie systemowym jest nią relewancja problemowa, oparta na słowach kluczach. Wszystkie procesy związane z wiedzą podporządkowane są rozwiązywaniu problemów. Identyfikacja problemów oraz ścieżek znalezienia właściwego rozwiązania prowadzi do utworzenia słownika słów kluczy, z którego korzystamy także przy zapisywaniu plików, czyli kreowaniu ich nazw.

Respektowanie Brzytwy Ockhama, jako jednego z pryncypiów, jest tutaj konsekwencją rozpoznawanego przez nas modelu organizacji, w której istotną wartością jest jej energia. Infrastrukturę techniczną, technologiczną można stosunkowo łatwo pozyskać, zmienić, odnowić. Z energią organizacji jest inaczej. Ma ona swoje źródło w relacjach międzyludzkich, w decyzyjności, kapitale ludzkim, komunikacji, by wymienić najważniejsze dziedziny. Utrata energii, potencjału działania organizacji jest konsekwencją obecności w niej takich stanów rzeczy, jak wspomniane wcześniej pętle zadaniowe. Nie chodzi tutaj jedynie o efekt utraty fizycznego potencjału działania, ale uwarunkowania pozbawiające działające podmioty sensu określonych czynności. Najogólniej rzecz ujmując, byty tworzone ponad niezbędną konieczność taką właściwość mają i sama ich obecność w organizacji jest swoistym katalizatorem procesu „rozładowywania energii organizacji”. Potocznie określa się to jako stan bezsilności, poczucie niemocy, braku szansy na zmianę. Te psychologiczne opisy

15 Nazwa ta używana jest zamiennie z zasadą ekonomii lub zasadą ekonomii myślenia. Zgodnie z nią w wyjaśnianiu zjawisk należy dążyć do prostoty, wybierając takie wyjaśnienia, które opierają się na jak najmniejszej liczbie założeń i pojęć.

${ }_{16}$ Nazwa nawiązuje do anegdoty opowiadającej o tym, jak Krzysztof Kolumb rzekomo miał rozwiązać zagadkę, jak ustawić jajko w pionie. Ustawił je, delikatnie naruszając skorupkę jajka. 
znajdują swoje potwierdzenie w braku potencjału zmian, atomizacji zespołu, jego bierności itd.

Przejawem braku respektowania omawianego pryncypium są wspomniane już wcześniej pętle zadaniowe, polegające na tym, że te same zadania wykonuje się w różnym czasie, angażuje w to różne zespoły, za każdym razem rozpoczynając zadanie od samego początku. Jeśli zadanie wymaga przygotowania ankiety i taka ankieta została już poprzednio sporządzona, to pomimo tego znów się ją przygotowuje. 0 poszczególnych incydentach tego typu wie zazwyczaj niewielka grupa, ale powtarzalność pętli zadaniowych skłania do powstawania przekonań blokujących zjawisko, które w skrócie nazywamy energiq̨ organizacji, wyrażającą się w gotowości do zmian, partnerstwie, atencji, współpracy i rezultatach takich jak synergia.

Sposób zapisywania plików powinien, zdaniem autora, blokować pętle zadaniowe. Przede wszystkim ze względu na realną możliwość wyszukania odpowiednich treści (pomimo braku środowiska aplikacyjnego i specjalistycznych rozwiązań informatycznych). Sposób zapisu jest, jak to zaznaczono wcześniej, rozwiązaniem informacyjnym, a nie informatycznym. Opisana w dalszej części rozważań formuła zapisu zawiera słowa klucze, ale nie jest to postać pełna.

Drugi z pryncypiów - Jajko Kolumba - jest nakazem poszukiwania rozwiązań prostych. Prostoty rozwiązań nie należy mylić z prostactwem. W myśleniu technicznym takim przykładem prostego rozwiązania jest koło. Każda z intelektualnych dziedzin refleksyjności wypracowała odrębne formuły prostoty jako wzorca rozwiązań. W omawianym przypadku należy odwołać się do walorów takich, jak obecność składników wybranego rozwiązania w innych rozwiązaniach stosowanych w tej samej dziedzinie. Powtarzalność elementów rozwiązania stwarza szansę jego pełniejszego wdrożenia. Rozwiązanie to respektuje zarazem zasadę Brzytwy Ockhama, gdyż fundament budujemy na jednej kategorii stanów rzeczy: na słowach kluczach. Tak więc proces zapisywania, tworzenia nazw plików opieramy:

- ideowo - na problemowej relewancji wiedzy,

- technicznie - na słowach kluczach,

- produktowo - na mapach myśli (mapy problemów, mapy wiedzy, drzewa decyzyjności), na kwantach wiedzy (argumentach me- 
rytorycznych z obszaru identyfikacji lub rozwiązania problemu) oraz na drzewach celów (piramidach wartości).

Warto zilustrować pewne fragmenty tego procesu na konkretnym przykładzie (rys. 5). Z listy problemów, które rozwiązuje organizacja, wybieramy utrzymywanie stałej przewagi nad silną konkurencją w branży. Taki stan rzeczy zmusza do ciągłej obserwacji firm konkurencyjnych, analizy ich zachowań oraz reagowania zapobiegającego uzyskaniu przewagi przez konkurentów. Wiedza, jaką gromadzi firma, skategoryzowana jest według wzorca opracowanego $\mathrm{w}$ trakcie procesu identyfikacji omawianego problemu.

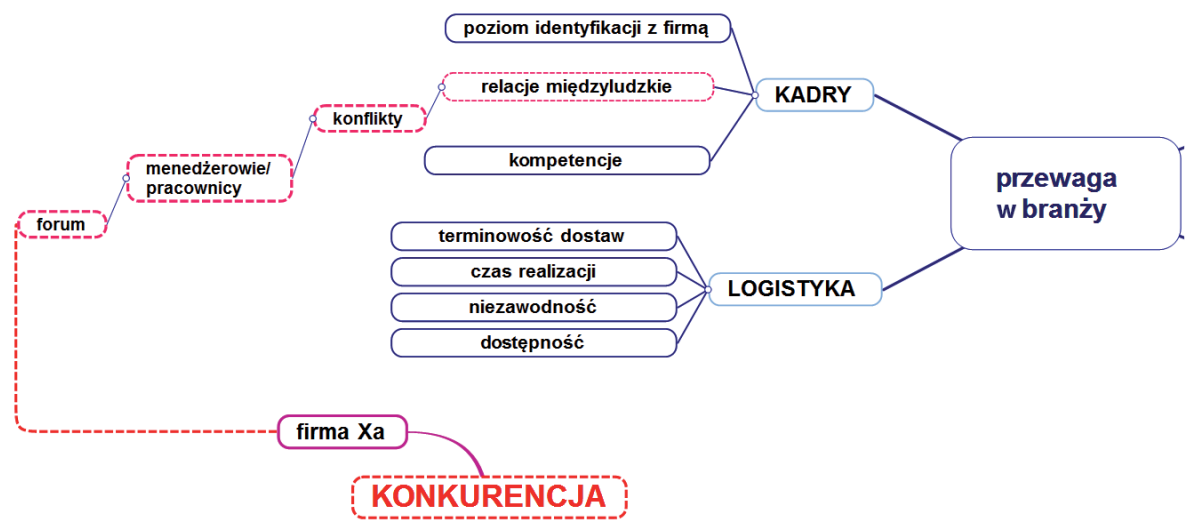

Rysunek 5. Mapa myśli - uwarunkowania przewagi w branży Źródło: opracowanie własne.

Załóżmy, że w organizacji wyszukano informację o konflikcie w firmie „Xa”, zamieszczoną na forum, gdzie pracownicy dyskutują między sobą o skandalicznych, ich zdaniem, zachowaniach własnej kadry menedżerskiej. Osoba, która wyszukała tę informację, stoi przed wyborem konstrukcji nazwy pliku. Chodzi o taki układ słów kluczy, aby ich dobór i układ ukierunkowywał odbiorców treści jednoznacznie na interesujący nas plik. Wspominaliśmy wcześniej o kategoryzacji problemów i mapowaniu myśli jako technice wspierającej ten proces. Odwołując się do przykładu ilustrującego opisywane zagadnienie, przytaczamy poniżej fragment mapy myśli jako rezultat kategoryzacji problemu „przewagi 
w branży”. Na przytoczonej mapie jedną z kategorii są „kadry”. Kolejne podgrupy to: „relacje międzyludzkie”, „konflikty”, „konflikty między menedżerami a pracownikami”, „fora dyskusyjne”. Warto przypomnieć, że interesujący nas materiał dotyczy sytuacji w firmie konkurencyjnej „XA”. W nazwie pliku cytującego wspomniane głosy na forum - sekwencja słów kluczy może być następująca:

konkurencja_firma XA_kadry_relacje międzyludzkie_konflikty_menedżerowie a pracownicy_forum

Zacytowany dobór oraz układ słów kluczy traktujemy tutaj jedynie jako przykład, który ma ilustrować omawiany wcześniej problem oraz pokazywać konkretną ścieżkę rozwiązania go. Jako wtórną traktujemy kwestię, dlaczego akurat taką, a nie inną kategorię identyfikacji problemu wybrano w cytowanym przykładzie, dlaczego wskazano taką czy inną podgrupę tematyczną. Jest to kwestia wtórna w tym sensie, że każdy zespół - stosownie do specyfiki swojej kultury organizacji, potrzeb i predyspozycji - jest w stanie wypracować optymalny dla siebie sposób identyfikacji i rozwiązywania problemów, selekcji słów kluczy, a w konsekwencji zapisywania nazw plików. Ważne jest dostrzeganie tego problemu i korzyści, jakie wynikają z prostych rozwiązań na poziomie nazewnictwa plików i na tym koncentrujemy naszą uwagę.

Istotne są ponadto pewne elementy rozwiązania, które są znamienne dla procesów komunikacji wiedzy, wspieranych przez praktykę infobrokerską, takie jak:

- respektowanie w całym systemie komunikacji wiedzy jednej zasady zapisywania nazw plików,

- pełna korelacja wspomnianej zasady ze strategią organizacji,

- traktowanie produktów finalnych oraz cząstkowych procesów komunikacyjnych jako aktywnie oraz istotnie wspierających model organizacji.

Przytoczona formuła zapisu nazw plików - w relacji do słowników słów kluczy przypisanych problemom - jest modułem zapisu, który może i powinien być uzupełniony o inne elementy. Wśród cech rozwiązań, którym przypisaliśmy powyżej szczególne preferencje, jest wspieranie modelu organizacji. Póki co nawiązaliśmy do organizacji inteligentnej, wskazując na elementy rozwiązania wspierające ten model. Zależnie 
od preferencji organizacji inne elementy będą zapewne ukształtowane odmiennie. Jeśli znajdzie się wśród nich np. partnerstwo, to możliwość produktowego wsparcia tego modelu formułą nazewnictwa plików wyrażać się może w obecności identyfikatora danego autora. Konkretne rozwiązanie może być takie, że w nazwie pliku używa się inicjałów i np. sześciocyfrowego kodu właściwego dla danego autora.

Autorstwo produktów pracy intelektualnej jest nie tylko praktyczną formułą respektowania partnerstwa i utrwalania w codziennej praktyce organizacji tego modelu, ale jest ponadto ważkim czynnikiem stymulującym tak istotne procesy komunikacyjne, jak dzielenie się wiedzą oraz dbałość o należytą jakość produktów pracy intelektualnej. Autorski charakter prac sprzyja aktualizacji wiedzy, jej reprezentatywności dla stanu wiedzy w danej dziedzinie, dostępności i obecności we wszystkich procesach komunikacji i decyzyjności. Pośrednio wpływać może korzystnie na relacje międzyludzkie i procesy kształtowania się liderów, gdyż zobiektywizowane rezultaty pracy są modułami transparentności i obiektywizacji ocen.

Tak więc ostateczny kształt proponowanej tutaj formuły zapisu nazw pliku mógłby ostatecznie przyjąć formę:

data_indeks autora_rodzaj produktu_wersja produktu_słowa klucze (konkurencja_firma XA_kadry_relacje międzyludzkie_konflikty_menedżerowie a pracownicy_forum)

Instrukcja zapisu sprawia wrażenie bardziej skomplikowanej procedury, niż jest nią w praktyce. Zapewne opis wielu czynności wykonywanych codziennie, wielokrotnie - jak choćby otwieranie drzwi - też takie wrażenie sprawia.

Formuła zapisu plików nie jest wprawdzie aplikacją informatyczną, której wdrożenie wymaga reorganizacji firmy, nakładów finansowych, kosztownych szkleń itd., ma jednak tego samego wroga, który odpowiedzialny jest za niepowodzenia licznych wdrożeń aplikacyjnych i olbrzymich, miliardowych strat poniesionych w projektach informatycznych. Jest to opór przed zmianami i respektowanie dawnych nawyków z jednoczesnym deklaratywnie pozytywnym nastawieniem do zmian jako postawy oczekiwanej przez pracodawcę. Dlatego w infobrokerstwie systemowym tak wielką wagę przypisuje się do rozpoznania infrastruktury 
intelektualno-mentalnej organizacji, zidentyfikowania przekonań realnie kształtujących jej przebieg.

\section{Wdrozienie formuły}

W realnej praktyce, $\mathrm{w}$ rutynowych działaniach firmy korzystają wprawdzie z wiedzy, ale przede wszystkim tej, którą mają „w głowach”. Część organizacji nie zapisuje niczego poza dokumentami koniecznymi do prowadzenia działalności oraz danymi kontaktowymi niezbędnymi do działań operacyjnych. W polskich realiach mowa jest tutaj przede wszystkim o podmiotach na poziomie mikroprzedsiębiorstwa czy firm małych i średnich, gdyż korporacje rozwiązują problemy komunikacyjne z wykorzystaniem potężnych narzędzi informatycznych i jako takie nie są z zasady zainteresowane rozwiązaniami informacyjnymi inicjowanymi z pozycji potrzeb konkretnych stanowisk pracy.

Praktyka konsultingowa oraz wieloletnie badania własne tego tematu potwierdzają, że teza o potencjalnych korzyściach wynoszonych z notowania pewnych treści jest dla praktyków deklaratywnie bezdyskusyjna. Natomiast brak respektowania tego zwyczaju w codzienności organizacji wyjaśnia się zazwyczaj brakiem czasu, pośpiechem, nawykami.

Stosunkowo najpowszechniejszym sposobem zapisywania wszystkiego, co mieści się w pojęciach danych, informacji, wiedzy czy szerzej treści, są w organizacjach funkcjonujących w polskich realiach pliki sytuowane zazwyczaj na lokalnych serwerach. Możliwości wyszukania potrzebnych elementów są w tych warunkach bardzo ograniczone. Powstaje dylemat, jak zmienić ten niekorzystny stan rzeczy, uwzględniając realia działania i pamiętając jednocześnie o propozycjach standaryzowania procesów komunikacji wiedzy.

Z perspektywy doświadczeń doradczych optymalnym rozwiązaniem jest zaistnienie nowej formuły zapisu na zasadach incydentów - dobrze wpisanych w aktualne potrzeby organizacji. Analogicznie jak z mapą myśli jako formą wizualizacji treści. Sensowne jest pojawienie się jej w krytycznym momencie dialogu, gdzie wyczerpano możliwości „tekstowe”, a wprowadzona wizualizacja ujawnia nowe ścieżki rozwiązań. Taki stan rzeczy pomaga w rozwiązaniu problemu i ujawnia walory mapowania. Analogicznie jest z kwantowaniem wiedzy. W przypadku ważkich decyzji, 
nad którymi zastanawia się zespół, poszukując optymalnego rozwiązania, dostarczenie istotnej przesłanki decyzyjnej w formule pakietu plików uporządkowanych zapisem może być wyśmienitym pretekstem do inicjacji interesujących nas wdrożeń.

Pozostaje najważniejsze bodaj pytanie o adresata niniejszych rozważań i jednocześnie sojusznika procesów wdrożeniowych opisanych rozwiązań. Przedsiębiorcy, menedżerowie zdają się nimi bezspornie. W przekonaniu autora są to jednak raczej beneficjenci, gotowi zaangażować się w przedsięwzięcie dopiero na pewnym etapie wdrażania projektu, wtedy kiedy ujawnią się pierwsze efekty, bardziej namacalne korzyści. Dlatego adresatami przedstawionych tutaj treści autor czyni przede wszystkim humanistów, gdyż wyprofilowanie ich kompetencji - czy to w formule studiów podyplomowych i nowych specjalności, czy specjalistycznych kursów - jest w stanie ukształtować umiejętności infobrokerskie, zapewniające w pierwszej kolejności korzyści ich posiadaczom. Kompetencje te zapewniają skuteczną, merytoryczną obecność w zespołach projektowych nastawionych na rozwiązywanie problemów.

Praktyka, szczególnie korporacyjna, rozpoznawania kompetencji pracowniczych pierwszej dekady XXI w. zdaje się tkwić (po trosze) w schizofrenicznej realności. W każdym razie w polskich uwarunkowaniach społeczno-gospodarczych. Z jednej bowiem strony akceptuje się deklaratywnie model społeczeństwa informacyjnego. Potwierdzeniem tego stanu rzeczy jest przyjęcie przez Polskę strategii Europa 2020 - opartej na takim modelu. $\mathrm{Z}$ drugiej natomiast nie rozpoznaje się - z konsekwencją wartą innej sprawy - kompetencji znamiennych dla organizacji funkcjonujących we wspomnianych realiach, a więc kompetencji informacyjnych. Sprowadza się je albo do informatycznych, albo ekonomicznych (zarządczych).

Tworzenie wiedzy jako produktu finalnego organizacji jest procesem tak samo specjalistycznym jak działania inżynieryjne. $\mathrm{Z}$ tą różnicą, że błąd inżynieryjny często skutkuje natychmiastowymi katastrofalnymi konsekwencjami, a błędy informacyjne, wynikające z braku optymalnej wiedzy, interpretowane są zazwyczaj jako błędy informatyczne lub ekonomiczne. Nawet jeśli jest to ewidentny błąd metodologiczny, jak stosowanie wiedzy poza obszarami jej zastosowań (przypadek rozwiązań kryzysu greckiego) - rozpoznawalny przez metodologicznie wyedukowanych humanistów, to wśród konkluzji z takich i podobnych incydentów 
nie ma wniosków kompetencyjnych w obszarze infobrokerskim, a więc takich jak:

- brak transparentności procesów decyzyjnych w zakresie uzasadnień merytorycznych,

- nieaktualne stany wiedzy w obszarach wsparcia procesów decyzyjnych,

- brak wiedzy skwantyfikowanej,

- brak dzielenia się doświadczeniem, szczególnie negatywnym itd.

W krótkiej perspektywie czasowej tak zauważalnych prima facie konsekwencji to mniej ważne. Ma to przełożenie na określenie wagi kompetencji i na traktowanie kompetencji informacyjnych jako mniej ważkich dla organizacji.

\section{Bibliografia}

Bonecki Mateusz, Interpretacja humanistyczna a teoretyczna rekonstrukcja kultury, „Filo-Sofija” 2011, nr 12, s. 189-211.

Bonecki Mateusz, Jerzy Kmita - interpretacja humanistyczna i społeczno-regulacyjna koncepcja kultury, „Filozofia Publiczna i Edukacja Demokratyczna” 2012, nr 2, s. 178-198.

Bonecki Mateusz, Sensemaking - wiedza i kultura organizacji w świetle humanistyki zintegrowanej, „Filo-Sofija” 2013, nr 18, s. 49-69.

Boruszewski Jarosław, Jakość i wiarygodność informacji w infobrokerstwie, „Lingua ac Communitas" 2012, vol. 22, s. 241-250.

Czapnik Grzegorz, Gruszka Zbigniew, Walczak-Niewiadomska Agata, Edukacja brokerów informacji na poziomie akademickim - zarys problematyki badań realizowanych $w$ Katedrze Bibliotekoznawstwa i Informacji Naukowej Uniwersytetu Łódzkiego, [w:] Biblioteka, książka, informacja i Internet 2010, pod red. Zbigniewa Osińskiego, Lublin 2010, s. 27-38.

Goldratt Eliyahu M., Łańcuch krytyczny, Warszawa 2009.

Gontarz Andrzej, Obywatel wszechwiedzący. Fiszki w urzędzie, „Computerworld” 2005, nr 12, s. 28-31.

Grad Jan, Jerzy Kmita - uczony, nauczyciel akademicki, organizator życia naukowego, popularyzator nauki, „Filo-Sofija” 2011, nr 12, s. 19-68. 
Infobroker systemowy [online]. CRM SA Devoteam Consulting Company [dostęp 31 maja 2014]. Dostępny w World Wide Web: http://www.crm.com.pl/ offer/27.

Kmita Jerzy, Interpretacja humanistyczna i społeczno-regulacyjna koncepcja kultury, „Filozofia Publiczna i Edukacja Demokratyczna” 2012, nr 2, s. 178$-198$.

Kmita Jerzy, Wymykanie się uniwersaliom, Warszawa 2002.

Kowalska Małgorzata, Infobroker - zawód z przyszłością [online]. Portal Innowacji [dostęp 31 maja 2014]. Dostępny w World Wide Web: http://pi.gov.pl/parp/ chapter_86196.asp?soid=AD8B4DA05ADE 4E13B02428383D6 BFF39.

Kozubek Elżbieta, Werner Piotr, Infrastruktura społeczna o znaczeniu międzynarodowym i krajowym - stan i prognoza. Pierwszy etap [online]. Warszawa: Ministerstwo Rozwoju Regionalnego, 2009, 35 s. [dostęp 31 maja 2014]. Dostępny w World Wide Web: http://www.mrr.gov.pl/rozwoj_regionalny/ Polityka_przestrzenna/KPZK/Ekspertyzy/Documents/Infrastruktura_spoleczna_o_znaczeniu_miedzynarodowym_i_kraj_etap129_05_09.pdf.

Marciszewski Witold, Szkice do współczesnej metodologii nauk społecznych [online]. Warszawa: Fundacja na rzecz Informatyki, Logiki i Matematyki, 2002 [dostęp 31 maja 2014]. Dostępny w World Wide Web: http://www.calculemus.org/SzkiceMet/index.html.

Oleński Józef, Infrastruktura informacyjna państwa w globalnej gospodarce, Warszawa 2006.

Pałubicka Anna, Gramatyka kultury europejskiej, Bydgoszcz 2013.

Pałubicka Anna, Opozycja dwóch postaw wobec świata a koncepcja kultury Jerzego Kmity, „Filo-Sofija” 2011, nr 12, s. 145-158.

Perechuda Kazimierz, Zarządzanie wiedzq w przedsiębiorstwie, Warszawa 2005. Radomski Andrzej, Wywiad z prof. Jerzym Kmitq, „Kultura i Historia” [online] 2002, nr 3 [dostęp 31 maja 2014]. Dostępny w World Wide Web: http:// www.kulturaihistoria.umcs.lublin.pl/archives/108.

Społeczeństwo informacyjne 2005, pod red. Grzegorza Bliźniuka, Jerzego Stanisława Nowaka, Katowice 2005.

Sułkowski Łukasz, Epistemologia w naukach o zarządzaniu, Warszawa 2005.

Wojewódzki Tadeusz, Infobroker a infobroker systemowy [online]. Infobrokerstwo.pl [dostęp 31 maja 2014]. Dostępny w World Wide Web: http:// infobrokerstwo.pl/index.php?option=com_content\&task=view\&id=202\&Itemid $=62$. 
Wojewódzki Tadeusz, Infobroker w organizacji [online]. Infobrokerstwo [dostęp 31 maja 2014]. Dostępny w World Wide Web: http://www.infobrokerstwo. pl/index.php?option=com_content $\&$ task=view\&id=64\& Itemid $=62$.

Wojewódzki Tadeusz, Infobrokerstwo - jako nowa płaszczyzna wsparcia administracji publicznej, [w:] Społeczeństwo informacyjne 2005, pod red. Grzegorza Bliźniuka, Jerzego Stanisława Nowaka, Katowice 2005, s. 161-172.

Wojewódzki Tadeusz, Jak blokować zagrożenia mentalne w zespole projektowym? [online]. Infobrokerstwo [dostęp 31 maja 2014]. Dostępny w World Wide Web: http://www.infobrokerstwo.pl/index.php?option=com_content\&task=view\&id=179\&Itemid=38; http://www.kwantywiedzy.pl/.

Wojewódzki Tadeusz, Jak zapisywać treści?, „Akademicka Gazeta Internetowa” [online] 8 września 2009 [dostęp 31 maja 2014]. Dostępny w World Wide Web: http://www.agiateneum.pl.

Wojewódzki Tadeusz, Jeśli nie wiadomo o co chodzi, „Zarządzanie Projektami. Magazyn" 2013, nr 1, s. 60-62.

Wojewódzki Tadeusz, Kultura projektowa organizacji - pochodna procesów integracyjnych z UE, „Studia i Badania Naukowe” 2006, nr 1, s. 153-173.

Wojewódzki Tadeusz, Regionalistyka jako nauka praktyczna, „Studia Filozoficzne” 1974, nr 7, s. 153-162.

Wojewódzki Tadeusz, Rekomendacja sukcesu w projekcie dużym i... małym, „Zarządzanie Projektami. Magazyn" 2013, nr 2, s. 54-56.

Wojewódzki Tadeusz, Rola PCM w kształtowaniu unijnej kultury organizacji, „Studia i Badania Naukowe. Europeistyka” 2011, nr 2, s. 125-139.

Wojewódzki Tadeusz, Twierdzenia optymalizacyjne w naukach społecznych, „Prakseologia" 1986, nr 1-2, s. 113-133.

Wojewódzki Tadeusz, Uwagi na kanwie sposobu myślenia, „Filo-Sofija” 2011, nr 12, s. 334-356.

Wojewódzki Tadeusz, Zarządzanie projektami [online]. Nf.pl [dostęp 31 maja 2014]. Dostępny w World Wide Web: http://manager.nf.pl/metodyka-zarzadzania-projektami,,13160,11.

Zarządzanie problemami i projektami w nowoczesnej organizacji, pod red. Lecha Zachera, Warszawa 2007.

Zarzq̨dzanie wiedzq jako kluczowy czynnik międzynarodowej konkurencyjności przedsiębiorstwa, pod red. Marka Jacka Stankiewicza, Toruń 2006. 


\section{Standardization of Contents Record as a Condition of Effective Infobroker's Practice}

ABSTRACT: Information broking education, both in the form of graduate studies and humanities specialties, systematically increases the number of graduates able to create an individual infobroking culture within organizations. This determines the effectiveness of decision-making processes and, consequently, the possibility to succeed and gain competitive advantage. The success is achieved using modern methods, appropriate for organizations that participate in the processes of knowledge creation as the final product.

Authorization of content sources, standardization of forms of recording, rationalization of processes of experience accumulation and knowledge sharing as well as optimization of transparent decision-making processes are basic actions that create the culture of modern organizations.

Infobroking practice ultimately leads to creation of specific content. This applies to infobroking understood both as classic services of searching information on demand as well as systems infobroking with its problematic relevance of knowledge and intellectual-mental conditions of organization. The effectiveness of the infobroking practice is generally recognized as content. However, content recording standards - starting at the level of the file name - are directly related to the level of knowledge communication process optimization. Analyzing these standards is looking for the optimal form of file names as the simplest and the most massive component of knowledge communication processes. In modern organizations these processes have become a critical factor in their effectiveness.

KEYWORDS: Infobroker's system; optimalization; quanta of knowledge; standardization of content. 
